This is a pre-copyedited, author-produced version of an article accepted for publication in the Industrial Law Journal following peer review. The version of record Alysia Blackham, 'Young Workers and Age Discrimination: Tensions and Conflicts' (2019) 48(1) Industrial Law Journal 1-33 is available online at: https://doi.org/10.1093/indlaw/dwy004

\title{
Young workers and age discrimination: tensions and conflicts
}

\author{
Alysia Blackham*
}

\begin{abstract}
Young workers occupy a particularly vulnerable position in the contemporary labour market. While this may partly be attributable to structural trends, it is also related to age discrimination, which is embedded in labour law and organisational practices. Age discrimination against younger workers raises many of the same tensions as age discrimination against older workers. This article therefore calls for a reconsideration of how we frame and conceive age discrimination law.
\end{abstract}

Keywords: age discrimination; United Kingdom; young workers

\section{Introduction}

Young workers occupy a particularly vulnerable position in the contemporary labour market. Many young people are excluded from employment entirely: in the quarter from October to December 2014, the unemployment rate in the UK for 16-24 year 
olds was $16.2 \%$, compared with $5.7 \%$ for the general working population, ${ }^{1}$ and $27 \%$ of unemployed 16-24 years olds had been unemployed for over 12 months. ${ }^{2}$ When they find work, young people are often consigned to insecure, precarious jobs. The Resolution Foundation estimates that $37 \%$ of those employed on zero-hours contracts are aged between 16 and $24 .{ }^{3}$ Over $40 \%$ of employees under 30 are employed in lowwage jobs, compared with $14.68 \%$ of those aged 30 to $49 ;{ }^{4}$ and only $68 \%$ of those aged under 35 are employed on an indefinite contract, compared with $85.7 \%$ for those aged 36 to $49 .{ }^{5}$ In sum, then, young workers are disproportionately occupying precarious jobs, ${ }^{6}$ and the growth in unpaid internships disproportionately affects younger workers. ${ }^{7}$

\footnotetext{
* Associate Professor and Discovery Early Career Research Fellow, Melbourne Law School, the University of Melbourne. This research was funded by the Australian Government through the Australian Research Council's Discovery Projects funding scheme (project DE170100228). The views expressed herein are those of the author and are not necessarily those of the Australian Government or Australian Research Council. The author would like to thank Professor Malcolm Sargeant for his comments on an earlier version of this article.

${ }^{1}$ James Mirza-Davies, 'Youth Unemployment Statistics' (Commons Library Standard Note, 26 February 2015) 1; ONS, 'Employment up 103,000 Compared with the Previous Quarter' (ONS, 18 February 2015) <http://ons.gov.uk/ons/rel/lms/labour-market-statistics/february-2015/sty-labourmarket-statistics--february-2015.html> accessed 3 March 2015.

${ }^{2}$ Mirza-Davies (n 1) 1.

${ }^{3}$ Matthew Pennycook and others, 'A Matter of Time: The Rise of Zero-Hours Contracts' (June 2013) 10.

${ }^{4}$ Eurostat Structure of Earnings Survey, 2010.

${ }^{5}$ Fifth European Working Conditions survey, 2010.

${ }^{6}$ See Renato Miguel Carmo and others, 'Time Projections: Youth and Precarious Employment' (2014) 23 Time Society 337.

${ }^{7}$ See Kayte Lawton and Dom Potter, 'Why Interns Need a Fair Wage' (2010) 5-6.
} 
This bleak picture of young workers' vulnerability may be partly attributable to the Crisis and structural changes in the labour market: in hard economic times, employers will be less willing to commit to training younger workers, and new secure jobs are less likely to be created. Further, the UK labour market has seen a decline in routine jobs, and an increase in non-routine service and managerial positions. ${ }^{8}$ The decline in routine occupations has meant that new labour market entrants (including younger workers) are more likely to enter low-wage service occupations with inferior terms and conditions of employment, potentially reducing upward occupational mobility. ${ }^{9}$

While young workers' challenging position in the labour market may therefore be partly attributable to structural trends, this ignores the historical prevalence of precarity for young workers: this is not a new phenomenon, and conditions for young workers have been of concern for many years. ${ }^{10}$ Unemployment for young people was substantially higher than for older adults from 1992 to $2014,{ }^{11}$ through both good economic times and bad. The historical prevalence of poor employment conditions for younger workers indicates that this is a systemic trend unlikely to be rectified with an upturn or structural changes in the economy.

\footnotetext{
${ }^{8}$ Craig Holmes and Ken Mayhew, The Changing Shape of the UK Job Market and its Implications for the Bottom Half of Earners (Resolution Foundation, 2012).

${ }^{9}$ ibid 21.

${ }^{10}$ See, for example, Paul Ryan, 'Trade Unionism and the Pay of Young Workers' in PN Junankar (ed), From School to Unemployment? (Palgrave Macmillan UK 1987).

${ }^{11}$ Tom McInnes and others, Monitoring Poverty and Social Exclusion 2014 (Joseph Rowntree Foundation 2014) 74.
} 
Some of these trends may be attributable to less favourable treatment in the labour market that disadvantages younger workers. A number of established employment practices may serve to disadvantage young workers, such as the use of lower youth wages for those under the age of 25 ; linking employment benefits to length of service or experience; and preferential treatment of older workers in cases of redundancy or termination. ${ }^{12}$ While these practices may be able to be justified (as will be discussed below), they likely undermine young people's labour market terms and conditions.

Going beyond these established practices, young workers also experience age discrimination in employment. Those aged under 30 report experiencing higher levels

\footnotetext{
${ }^{12}$ These practices may be distinguished from laws that protect children and young people from particular employment risks experienced, at least in part, due to their age. See, for example, Council Directive 94/33/EC of 22 June 1994 on the protection of young people at work, which makes provision for employers' general obligations in relation to workers aged under 18; explicitly prevents certain types of work being undertaken by those under that age; and specifies working hours, night working, rest periods, annual leave and rest breaks for those under 18. In the UK, see Working Time (Amendment) Regulations 2002 (UK) SI 2002/3128; Management of Health and Safety at Work Regulations 1999 (UK) SI 1999/3242 reg 19; and Education and Skills Act 2008 (UK) c 25 ss 1-2, which requires that young people continue in some form of education or training until the age of 18 . This article does not consider these protective provisions in detail, though the tensions discussed herein could also relate to protective legislation. Protective provisions, though, also engage an additional dichotomy between paternalism and autonomy for young workers: see Sandra Fredman and Sarah Spencer, 'Introduction' in Sandra Fredman and Sarah Spencer (eds), Age as an Equality Issue (Hart 2003) 7; Jonathan Herring, ‘Children's Rights for Grown-Ups' in Sandra Fredman and Sarah Spencer (eds), Age as an Equality Issue (Hart 2003) 150-54.
} 
of age discrimination than other age groups, making discrimination against young people at least as widespread as against older workers. ${ }^{13}$ In an experimental study of matched-pairs of written job applications, Riach and Rich found discrimination against both older and younger applicants in hiring processes, with a statistically significant preference for older applicants for retail sales jobs ${ }^{14}$ evidencing discrimination against younger applicants in recruitment. Similarly, in the 2010 UK Survey of Employers' Policies, Practices and Preferences Relating to Age ('SEPPP2'), $10 \%$ of establishments that had recruited in the last five years said that age affected selection for their largest occupational group; and $11 \%$ said that there were some ages that counted against applicants. Those most often disadvantaged on the grounds of age were the young and the old, particularly those aged under $22 .{ }^{15}$ Despite the prevalence of young age discrimination, there has been minimal consideration of age discrimination against young workers in academic research, resulting in an 'ageist ageism literature'. ${ }^{16}$ Studies of younger workers in employment have rarely extended to considering age discrimination in the workplace, and studies of age discrimination have rarely extended to discrimination against younger workers. ${ }^{17}$

\footnotetext{
${ }^{13}$ Ed Snape and Tom Redman, 'Too Old or Too Young? The Impact of Perceived Age Discrimination' (2003) 13 Human Resource Management Journal 78, 82, 87.

${ }^{14}$ Peter A Riach and Judith Rich, 'An Experimental Investigation of Age Discrimination in the English Labor Market' [2010] Annals of Economics and Statistics 169, 177.

${ }^{15}$ Hilary Metcalf and Pamela Meadows, 'Second Survey of Employers' Poicies, Practices and Preferences Relating to Age, 2010' (DWP Research Report, 2010) 33-34.

${ }^{16}$ Karen Rodham, 'Ageism, Young Academics and the Buffalo Stance' in Ian Glover and Mohamed Branine (eds), Ageism in Work and Employment (Ashgate 2001) 176-77.

17 Though see Malcolm Sargeant, 'Young Workers and Age Discrimination' (2010) 26 International Journal of Comparative Labour Law and Industrial Relations 467.
} 
This article addresses this gap, by considering the theoretical challenges of young age discrimination, and the extent to which the inherent tensions of young age discrimination affect the ability of age discrimination law to protect young people's interests. I argue that the vulnerable position of younger workers is at least partly attributable to less favourable treatment on the grounds of age. While younger workers are protected by age discrimination legislation in the UK, this statutory framework is plagued by tensions between economic or instrumental ends, and intrinsic or dignity ends. This manifests in conflicts between integration, productivity and intergenerational fairness on the one hand, and individual dignity on the other. Many of these tensions reflect the same conflicts evident in age discrimination against older workers. In this article, then, I map these tensions, using case studies of youth wages, dismissal and redundancy to explore how theoretical tensions are potentially undermining legal protection for younger workers.

\section{The legal framework}

Age discrimination legislation has significant potential to assist younger workers. By prohibiting direct and indirect discrimination in employment on the basis of age, Council Directive 2000/78/EC of 27 November 2000 establishing a general framework for equal treatment in employment and occupation ${ }^{18}$ ('the Framework Directive') and the Equality Act 2010 ('the EqA') offer young workers the chance to challenge discriminatory conduct and practices.

\footnotetext{
18 [2000] OJ L303/16.
} 
The EqA prohibits direct and indirect discrimination, harassment and victimisation in the workplace on the grounds of age in recruitment, setting employment terms, awarding promotions, providing training and dismissal. ${ }^{19} \mathrm{~A}$ reference to 'age' as a protected characteristic is broadly defined as a person or persons of a particular age group, with an 'age group' being a group of persons defined by reference to 'a particular age or to a range of ages' ${ }^{20}$ This, then, includes workers of all ages - both young and old. This not universally accepted as an appropriate approach to age discrimination law: in the USA, for example, age discrimination law only applies to workers over the age of 40 .

Under the EqA, direct age discrimination can be justified as 'a proportionate means of achieving a legitimate aim'. ${ }^{21}$ Indirect discrimination may also be justified as a proportionate means of achieving a legitimate aim. ${ }^{22}$ The EqA therefore provides less protection for age discrimination in employment than for other forms of discrimination, as both direct and indirect age discrimination may be justified. Schedule 9 of the EqA makes a number of specific exceptions to the prohibition of age discrimination, including for: occupational requirements that are a proportionate means of achieving a legitimate aim; ${ }^{23}$ service in the armed forces; ${ }^{24}$ benefits based on length of service that relate to a period of service of up to five years, or to service of more than five years and which the employer reasonably believes fulfil a business

\footnotetext{
${ }^{19}$ EqA s 39.

20 ibid s 5 .

${ }^{21}$ ibid s 13(2).

22 ibid s 19(2).

${ }^{23}$ ibid sch 9, s 1(1).

24 ibid sch 9, s 4(3).
} 
need; ${ }^{25}$ the national minimum wage; ${ }^{26}$ enhanced redundancy payments; ${ }^{27}$ and contributions to personal pension schemes (by order of a Minister). ${ }^{28}$ Young workers in particular may be disadvantaged by the wide range of exceptions to the prohibition of age discrimination, particularly in relation to pay rates, redundancy payments and benefits based on length of service.

Age discrimination legislation in the UK and EU has a number of doctrinal limitations, including: extensive exceptions to the principle of age equality; ${ }^{29}$ the ability to objectively justify direct age discrimination $;{ }^{30}$ significant legal uncertainty, particularly around the objective justification process $;{ }^{31}$ and dependence on individual enforcement. These limitations substantially undermine the efficacy of age discrimination legislation for workers of all ages. However, these issues are compounded in relation to young age discrimination, which raises particular theoretical challenges, further limiting the utility of age discrimination law. It is these additional challenges that are the subject of this article.

\footnotetext{
25 ibid sch 9, s 10.

${ }^{26}$ ibid sch 9, ss 11-12.

27 ibid sch 9, s 13.

28 ibid sch 9, s 16.

${ }^{29}$ See further Malcolm Sargeant, 'Distinguishing between Justifiable Treatment and Prohibited Discrimination in Respect of Age' (2013) 4 Journal of Business Law 398, 415-16.

${ }^{30}$ See further ibid 403; Sandra Fredman, Discrimination Law (Clarendon Law Series, 2nd edn, Oxford University Press 2011) 190-98.

${ }^{31}$ See, for example, Elaine Dewhurst, 'Proportionality Assessments of Mandatory Retirement Measures: Uncovering Guidance for National Courts in Age Discrimination Cases' (2016) 45 Industrial Law Journal 60; Simonetta Manfredi and Lucy Vickers, 'Pensioning off the Mandatory Retirement Age: Implications for the Higher Education Sector' (2013) 33 LS 289, 311.
} 


\section{Tensions of young age discrimination law}

Age discrimination law is limited by a lack of clarity regarding its aims and objectives. ${ }^{32}$ While age discrimination law could be seeking to achieve a range of objectives - such as individual dignity, economic ends, and/or the removal of disadvantage on the basis of age - it is unclear which aim is to be prioritised, particularly where these aims are inconsistent or contradictory. ${ }^{33}$ For Manfredi and Vickers, then, there is 'a fundamental tension at the heart of the call for age equality ${ }^{34}$ between two key overarching objectives or aims: first, recognising the intrinsic worth and dignity of workers of all ages, via equal treatment; ${ }^{35}$ and, second, increasing the efficiency of organisations and labour markets, by avoiding irrational and economically inefficient prejudice. ${ }^{36}$ This could be framed as a tension between the individual right not to be discriminated against and labour market needs, ${ }^{37}$ or between human rights and economic justifications. ${ }^{38}$ Hendrickx sees this as the

\footnotetext{
${ }^{32}$ Manfredi and Vickers (n 31) 310.

${ }^{33}$ ibid.

${ }^{34}$ ibid 311.

${ }^{35}$ Simonetta Manfredi and Lucy Vickers, 'Retirement and Age Discrimination: Managing Retirement in Higher Education’ (2009) 38 Ind Law J 343, 344.

${ }^{36}$ ibid 344-45. See similarly Fredman (n 30) 105-08; Judy Fudge and Ania Zbyszewska, 'An Intersectional Approach to Age Discrimination in the European Union: Bridging Dignity and Distribution?' in Ann Numhauser-Henning and Mia Rönnmar (eds), Age Discrimination and Labour Law: Comparative and Conceptual Perspectives in the EU and beyond (Studies in employment and social policy 47, Kluwer Law International 2015) 144-45.

${ }^{37}$ Malcolm Sargeant, 'The Default Retirement Age: Legitimate Aims and Disproportionate Means' (2010) 39 Ind Law J 244, 247.

${ }^{38}$ Sargeant, 'Distinguishing between Justifiable Treatment and Prohibited Discrimination in Respect of Age' (n 29 ) 399. See similarly Ann Numhauser-Henning, 'The EU Ban on Age-Discrimination and
} 
'double bind' of age discrimination law, representing the tension between collective and individual interests. ${ }^{39}$ While Fredman recognises the tension between economic or market concerns and equality, ${ }^{40}$ and the resultant conflict between the instrumental and intrinsic aims of age discrimination law, ${ }^{41}$ she argues that age discrimination law is primarily derived from an economic impetus - not some 'sudden appreciation of the need for fairness' ${ }^{42}$ Thus, it is more likely that economic objectives will be prioritised in the event of conflict. ${ }^{43}$ This could lead to broader tolerance of exceptions to the equal treatment principle. ${ }^{44}$

Older Workers: Potentials and Pitfalls' (2013) 29 International Journal of Comparative Labour Law and Industrial Relations 391, 401.

${ }^{39}$ Frank Hendrickx, 'Age and European Employment Discrimination Law' in Frank Hendrickx (ed), Active Ageing and Labour Law: Contributions in Honour of Professor Roger Blanpain (Intersentia 2012) 21. See similarly Numhauser-Henning (n 38) 402. For further analysis of the differences between individual rights and collective approaches to mandatory retirement, see Julie C Suk, 'From Antidiscrimination to Equality: Stereotypes and the Life Cycle in the United States and Europe' (2012) 60 The American Journal of Comparative Law 75.

${ }^{40}$ Fredman (n 30) 35.

${ }^{41}$ ibid 106.

${ }^{42}$ ibid 103-04.

${ }^{43}$ D Schiek, 'Age Discrimination before the ECJ - Conceptual and Theoretical Issues' (2011) 48 Common Market Law Review 777, 778-79. See similarly Susan Bisom-Rapp and Malcolm Sargeant, 'Diverging Doctrine, Converging Outcomes: Evaluating Age Discrimination Law in the United Kingdom and the United States' (2012-13) 44 Loy U Chi LJ 717, 722, who argue that this undermines the efficacy of age discrimination law, and needs to be rebalanced. That said, instrumental and intrinsic ends might actually converge or help each other in certain circumstances: Fredman (n 30) 36. This is addressed in more detail below.

${ }^{44}$ Sargeant, 'Distinguishing between Justifiable Treatment and Prohibited Discrimination in Respect of Age' (n 29) 415-16. 
Thus, age discrimination law represents a negotiated tension between individual rights or dignity on the one hand, and instrumental or economic objectives on the other. Given both direct and indirect age discrimination may be justified under the EqA, distinguishing between what discrimination is acceptable, and what is unacceptable, sits at the heart of age discrimination law. ${ }^{45}$ This requires complex normative judgements about the instrumental benefits of discrimination, and when they should give way to the principle of equality. ${ }^{46}$ While 'young' age discrimination poses fundamental theoretical challenges and tensions in this context, in the sections that follow I argue that these tensions are remarkably similar for both young and old age discrimination. Thus, the tension at the heart of age discrimination law remains the same, whether we consider the situation of older or younger workers. I frame this argument by considering three key tensions in age discrimination law, namely between individual dignity and the instrumental ends of integration, productivity, and intergenerational fairness.

\section{A. Promoting integration}

A key tension in age discrimination law relates to the potential conflict between achieving an age diverse workforce, and promoting the integration of workers of all

\footnotetext{
${ }^{45}$ Fredman (n 30) 101.

${ }^{46}$ Or, if taking individual rights as a starting point, the question should be reframed as: when should the principle of equality give way to the instrumental benefits of discrimination? See Malcolm Sargeant, 'The Employment Equality (Age) Regulations 2006: A Legitimisation of Age Discrimination in Employment' (2006) 35 Ind Law J 209, 218.
} 
ages into the economy; ${ }^{47}$ and securing individual dignity and equal treatment. For some, being involved in paid employment is a key means of securing individual dignity, as it allows full participation in social and economic systems, and is important for sustaining an adequate standard of living. ${ }^{48}$ Thus, Fredman sees vocational integration as an intrinsic aim of age equality law. ${ }^{49}$ However, not all jobs are objectively 'good' or well adapted for securing individual dignity. Poor pay, working conditions or treatment can undermine individual dignity. ${ }^{50}$ Thus, while dignity can be achieved at work, poor work can undermine individual dignity. Securing an age diverse workforce, and promoting workforce participation of older and younger workers, is therefore not sufficient, in and of itself, to achieve individual dignity: attention must be paid to the quality of work offered to that age diverse workforce. This reflects the potential conflict between these two aims.

If an aim of age discrimination law is to achieve an age diverse workforce, this could lead to greater tolerance of exceptions to the equality principle, which are potentially in the long-term best interests of creating a diverse workforce. ${ }^{51}$ Exceptions may be required to achieve age diversity in practice, to encourage employers to recruit and retain non-'prime-age' workers. This is explicitly acknowledged in Article 6(1) of the Framework Directive, which gives examples of

\footnotetext{
${ }^{47}$ Regulatory Impact Assessment for the Employment Equality (Age) Regulations 2006, SI 2006/1031, [3].

${ }^{48}$ Randy Hodson, Dignity at Work (Cambridge University Press 2001) 3.

${ }^{49}$ Fredman (n 30) 106.

${ }^{50}$ Sharon C Bolton, 'Dignity in and at Work: Why It Matters' in Sharon C Bolton (ed), Dimensions of Dignity at Work (Elsevier 2007) 8.

${ }^{51}$ Sargeant, 'The Employment Equality (Age) Regulations 2006' (n 46) 218.
} 
different treatment on the grounds of age that may be objectively justified, including 'the setting of special conditions on access to employment and vocational training, employment and occupation, including dismissal and remuneration conditions, for young people [and] older workers ... in order to promote their vocational integration'. This, however, runs directly counter to the desire to eliminate less preferential treatment on the grounds of age, and the strictures of an individual rights perspective. $^{52}$

Thus, there is an enduring tension in this area between economic integration and individual rights. For older workers, this is manifested, for example, in exceptions allowing workers over a specified age to be hired on fixed-term contracts. In $\mathrm{C}-$ 144/04 Mangold $v$ Helm,${ }^{53}$ a domestic law permitting employers to enter into fixedterm contracts with workers over the age of 52 was challenged as being inconsistent with the Framework Directive. The CJEU held that the measure aimed to 'promote the vocational integration of unemployed older workers, in so far as they encounter considerable difficulties in finding work', and that ' $[\mathrm{t}]$ he legitimacy of such a publicinterest objective cannot reasonably be thrown in doubt' ${ }^{54}$ However, the specific provision in this case went beyond what was appropriate and necessary to achieve that aim, as it applied to all older workers, regardless of their labour market position. ${ }^{55}$

\footnotetext{
52 ibid.

${ }^{53}$ [2006] 1 CMLR 43.

${ }^{54}$ ibid paras 59-60.

${ }^{55} c f$ the provision in C-250/09 Georgiev v Tehnicheski Universitet - Sofia [2010] ECR I-11869, which only allowed for fixed-term contracts from the age of 65 (once university professors were entitled to a pension) until the age of 68. While not making a final decision on this point, the CJEU held that the use of fixed-term contracts in this way could be appropriate and necessary for achieving the legitimate
} 
Thus, it unacceptably undermined individual employment rights and security for older workers, including those who were already integrated into the labour market. ${ }^{56}$ While fixed-term contracts may therefore be an acceptable tool for promoting the integration of older workers into the labour market, they can only be implemented in a way that balances integration with individual employment rights.

For younger workers, this tension is revealed in the endurance of youth wages. 'Special conditions' that place downward pressure on young workers' terms and conditions of work are assumed to improve young workers' employment prospects, ${ }^{57}$ promoting their integration into the workplace. This relies on the 'standard economic premise' of an inverse relationship between relative price and demand. ${ }^{58}$ It is understandable that governments would look to 'special conditions' to promote young workers' integration in the economy, particularly in the face of intractable youth unemployment: promoting work integration of younger workers could be seen as an urgent priority for governments, and worth compromising individual rights to achieve.

Youth wages are a key 'special condition' in the UK. Minimum hourly wage rates and the National Minimum Wage ('NMW') vary by age, as depicted in Table

aims of 'allocating the posts for professors in the best possible way between the generations' and encouraging the recruitment of younger professors: paras 45-46, 66. The integration of older professors into the workforce was not relied on as an aim of the provision.

${ }^{56}$ Mangold (n 53) paras 64-65.

${ }^{57}$ David Plowman, 'Wage Differentials and Youth Unemployment' (1994) 5 The Economic and Labour Relations Review : ELRR 21.

${ }^{58}$ John Mangan and John Johnston, 'Minimum Wages, Training Wages and Youth Employment' (1999) 26 International Journal of Social Economics 415. 
1. ${ }^{59}$ From April 2016, a National Living Wage ('NLW') has been introduced for workers over 25 , meaning 'adult' wage rates now only apply to 21 to 24 year olds. This effectively extends lower youth wages to those under 25 (not 21, as was previously the case).

\begin{tabular}{lllll}
\hline 25 and over & $\mathbf{2 1}$ to 24 & $\mathbf{1 8}$ to 20 & Under 18 & Apprentice \\
\hline$£ 7.50$ & $£ 7.05$ & $£ 5.60$ & $£ 4.05$ & $£ 3.50$ \\
\hline
\end{tabular}

Table 1: 2017 Minimum hourly wage rates, UK

In justifying lower levels of pay for those under 25, the Conservative government distinguished their goals for the general working population from their goals for younger workers. For the general working population, the government viewed the 2015 Summer Budget as 'the right time to take action to tackle low pay and ensure that lower wage workers can take a greater share of the gains from growth', ${ }^{60}$ including through the introduction of the NLW. The government wished 'to see a higher wage for more experienced workers and so is introducing a premium for workers aged 25 and over. ${ }^{61}$ However, younger workers were excluded from this vision of a 'higher wage, lower tax, lower welfare society'. ${ }^{62}$ Instead, for young workers, 'the priority is to secure work and gain experience, which is already

\footnotetext{
${ }^{59}$ See further National Minimum Wage Act 1998; National Minimum Wage Regulations 1999 SI 1999/584.

${ }^{60}$ HM Treasury, 'Summer Budget 2015’ (8 July 2015) 32-33.

${ }^{61}$ Department for Business Innovation and Skills, 'Final Government Evidence for the Low Pay Commission's 2016 Report' (January 2016) 11 (emphasis added).

${ }^{62}$ HM Treasury (n 60) 32.
} 
reflected in the existing [NMW] rate structure. ${ }^{63}$ Maximising 'opportunities' for younger workers to gain experience ${ }^{64}$ was prioritised over 'tackling low pay', preferring work (of any quality) and the 'employment prospects of younger workers ${ }^{965}$ over their financial wellbeing.

There is increasing recognition that lower minimum wages for young workers do not affect youth employment: ${ }^{66}$ even the government recognises there is 'little evidence' that youth wages have 'impacted on the employment prospects of this group to date' ${ }^{67}$ Taken in context, Mangan and Johnston argue that wages are not a major factor in determining youth employment rates. ${ }^{68}$ Thus, 'special conditions' for

\footnotetext{
${ }^{63}$ ibid 34.

${ }^{64}$ ibid.

${ }^{65}$ Department for Business Innovation and Skills (n 61) 25-26.

${ }^{66}$ Shobana Nair Sehkaran and Rosemary Lucas, The National Minimum Wage and Young Workers: A
} Comparison between Urban and Rural Areas (Centre for Hospitality Employment Research 2001); Grant Belchamber, 'Minimum Award Wages for Young Workers Must Be Reformed' (1999) 32 Australian Economic Review 390.

${ }^{67}$ Department for Business Innovation and Skills (n 61) 25-26.

${ }^{68}$ Mangan and Johnston (n 58). However, some studies have found that increases in adult minimum wages may negatively affect the employment prospects of young workers: Stephen Bazen and Nicolas Skourias, 'Is There a Negative Effect of Minimum Wages on Youth Employment in France?' (1997) 41 European Economic Review 723; John M Abowd and others, 'Minimum Wages and Youth Employment in France and the United States' in David G Blanchflower and Richard B Freeman (eds), Youth Employment and Joblessness in Advanced Countries (University of Chicago Press 2000); David Neumark and William Wascher, 'Minimum Wages, Labor Market Institutions, and Youth Employment: A Cross-National Analysis' (2004) 57 ILR Review 223. This is particularly the case in countries with low levels of labour market regulation: see ibid 243. However, these studies do not consider the impact of youth wages specifically, and changes to the adult minimum wage are likely to 
young people may not be a proportionate means of achieving young people's vocational integration in the labour market, and the 'integration' argument may not be sufficient to justify detracting from individual rights. ${ }^{69}$

Despite these concerns, special conditions to achieve young people's vocational integration have been endorsed in principle by the CJEU. In C-88/08 Hütter $v$ Technische Universität Graz, ${ }^{70}$ the Member State argued that excluding periods of employment before the age of 18 when determining the incremental pay step for public servants pursued legitimate aims of not treating general education less favourably than vocational education, and promoting the integration of young apprentices into the labour market. The CJEU held that, while the aims were legitimate in principle, ${ }^{71}$ excluding service under the age of 18 from the pay calculation could not be regarded as appropriate for achieving those aims. Under the provisions, experience acquired before the age of 18 was excluded for all public servants, regardless of the age at which they were recruited. Therefore, the provision did not 'single out a group of persons defined by their youth in order to give them special conditions of recruitment intended to promote their integration into the labour market'. ${ }^{72}$ The provision was therefore not appropriate for promoting the entry into the labour market of a category of workers defined by their youth, as it did not take

\footnotetext{
have more impact on youth employment rates in the absence of youth wages: ibid 236. Further, these findings are likely to be influenced by a sizeable number of country-specific variables: see Neumark and Wascher.

${ }^{69}$ Colm O’Cinneide, 'Age Discrimination and European Law' (April 2005) 44.

${ }^{70}$ [2009] All ER (EC) 1129.

${ }^{71}$ ibid para 43.

72 ibid para 49.
} 
into account workers' age at the time of their recruitment. ${ }^{73}$ The CJEU explicitly distinguished the provisions at hand from those 'designed to promote the integration of young people below the age of 18 into the labour market, in so far as those measures provide minimum conditions of pay for such young people that are below those for older workers' ${ }^{74}$

Thus, measures aimed at the recruitment and integration of younger workers, and which specifically take into account younger workers' age at the time of recruitment, are likely to be proportionate, despite their potential impact on individual rights. This implies that the CJEU would likely uphold UK minimum wage provisions, to the extent they are attempting to facilitate young people's integration in the labour market. However, the exclusion of those under 25 from the NLW may go beyond what is required to promote young people's integration: the government would need strong evidence to support such a provision. Given its own recognition that there is 'little evidence' that youth wages have influenced the employment prospects of younger workers, ${ }^{75}$ this would appear to be lacking.

More generally, the use of 'special conditions' to push down younger workers' terms and conditions of employment can have serious consequences in practice, and risks undermining younger workers' dignity. Reduced youth wages undermine young

\footnotetext{
${ }^{73}$ ibid.

${ }^{74}$ ibid. See also C-530/13 Schmitzer v Bundesministerin für Inneres [2015] 1 CMLR 50 5LEpand C417/13 ÖBB Personenverkehr AG v Starjakob [2015] EUECJ (28 January 2015), where it was held that a transitional scheme maintained this age discrimination in pay rates, and was therefore not appropriate.

${ }^{75}$ Department for Business Innovation and Skills (n 61) 25-26.
} 
people's financial independence and contribute to family poverty. ${ }^{76}$ Indeed, young people in the UK are disproportionately at risk of poverty and social exclusion: in $2013,32.5 \%$ of those aged 16-24 were at risk, compared with $22.4 \%$ of those aged 25 to $49 .{ }^{77}$ Lowering young people's employment entitlements contributes to this risk of poverty, and supports the growth of low-pay work: in $2010,40.6 \%$ of workers aged under 30 were employed in low-wage jobs, compared with $14.7 \%$ of those aged 30 to $49 .{ }^{78}$

In sum, then, youth wages serve to reinforce and endorse low-pay work for younger workers, without necessarily promoting their economic integration and inclusion. Thus, the balance that has been struck - which prioritises integration over individual rights and dignity - is inappropriate, and fails to adequately address or navigate this tension in age discrimination law. The resolution of this tension between integration and dignity needs to be reviewed, to better protect younger workers' interests.

\section{B. Productivity and efficiency}

A second tension in age discrimination law relates to the balance between achieving productivity and efficiency, and securing individual dignity and equal treatment. The 'business case' for equality emphasises the productivity and efficiency gains that can be achieved by avoiding irrational stereotyping and achieving an age diverse

\footnotetext{
${ }^{76}$ Jean Mulholland, Young Workers the New Poor? (West Midlands Low Pay Unit 1985) 2.

${ }^{77}$ Eurostat Statistics on Income and Living Conditions, 2013.

${ }^{78}$ Eurostat Structure of Earnings Survey, 2010. Young workers' financial needs are considered further in Part 3C below.
} 
workforce.$^{79}$ If we assume that merit is distributed equally across the population regardless of age - then achieving an age diverse workforce will allow employers to maximise the potential of their staff. This reflects 'crowding theory', or the idea that employers will benefit from a broader pool of employee talent if discriminatory barriers are eliminated. ${ }^{80}$ Thus, productivity and individual rights may not be in tension at all, but may be mutually supportive. ${ }^{81}$

However, as Fredman argues, this 'rhetoric of convergence' might serve to obscure the extent to which the market or productivity trumps equality. ${ }^{82}$ For older workers, for example, employers' fear of decline in older age ${ }^{83}$ is one driving force behind the retention of mandatory retirement ages: the 'dignity' legitimate aim recognises that employers may wish to remove older workers from the workforce, without the 'indignity' of performance processes ${ }^{84}$ As well as protecting the 'dignity' of older workers and their employers, this will help to maintain organisational productivity and efficiency, as potentially sub-standard employees are removed from

\footnotetext{
${ }^{79}$ See, for example, Sandra Fredman, 'The Age of Equality' in Sandra Fredman and Sarah Spencer (eds), Age as an Equality Issue: Legal and Policy Perspectives (Hart 2003) 48. Though, of course, it might also be economically efficient (at least in the short term) to exploit some groups of workers, and young workers in particular. This flags some of the difficulties with prioritising 'efficiency' arguments in the context of equality law.

${ }^{80}$ Anne CL Davies, Perspectives on Labour Law (Law in Context, 2nd edn, Cambridge University Press 2009) 129.

${ }^{81}$ Fredman (n 30) 36.

82 ibid.

${ }^{83}$ Sargeant, 'The Default Retirement Age: Legitimate Aims and Disproportionate Means' (n 37) 250.

${ }^{84}$ Seldon v Clarkson Wright \& Jakes (A partnership) [2012] UKSC 16 (25 April 2012), [2012] 2 CMLR 50, [57]-[58]. The other aim, intergenerational fairness, is considered below.
} 
the workforce. As Lady Hale acknowledged in Seldon v Clarkson Wright \& Jakes, '[t]he assumptions underlying these objectives look suspiciously like stereotyping' in relation to older workers' capacity. ${ }^{85}$ Despite this, a need to maintain high productivity and organisational efficiency, and a desire to avoid humiliating older workers whose performance is in decline, is seen as a legitimate aim in this context.

Similarly, a concern that younger workers will be less productive and efficient than other workers has led to less preferential treatment on the grounds of age. Lower youth wages, for example, are often explained on the basis that younger workers are less skilled and productive than their older colleagues: ${ }^{86}$ the lower productivity of younger workers was a key justification for not extending the NLW to those under $25 .{ }^{87}$ Equally, seniority pay is seen as recognising the higher productivity, skill, experience and loyalty of longer-term workers. In SEPPP2, 16\% of establishments that had recruited in the last five years said that age influenced starting pay for their largest occupational group, and in only $9 \%$ of establishments was this linked to youth pay rates. ${ }^{88}$ Further, pay rates generally were influenced by age (other than through the use of youth rates) in $1 \%$ of establishments, and $42 \%$ indicated that pay was

\footnotetext{
${ }^{85}$ Ibid [57].

${ }^{86}$ Malcolm Sargeant, 'The UK National Minimum Wage and Age Discrimination' (2010) 31 Policy Studies 351, 353.

${ }^{87}$ Then Cabinet Office minister Matthew Hancock, quoted in Matt Dathan, 'Workers under 25 "Don”t Deserve Living Wage Because They're Not as Productive,' Says Tory Minister', The Independent (London, 7 October 2015) <http://www.independent.co.uk/news/uk/politics/workers-under-25-dontdeserve-living-wage-because-theyre-not-as-productive-says-tory-minister-a6683851.html> accessed 12 August 2016.

${ }^{88}$ Metcalf and Meadows (n 15) 37.
} 
affected by the number of years of relevant job experience, and $28 \%$ by length of service. ${ }^{89}$ Of establishments with incremental pay scales, $51 \%$ had increments based on length of service ( $43 \%$ of which extended beyond five years), and $4 \%$ had increments based on age. ${ }^{90}$ Seniority, experience and length of service are also often used as a criterion in selecting for redundancy, ${ }^{91}$ including via the 'last in, first out' rule. This serves to both acknowledge and reward employee experience and 'loyalty', which is assumed to increase with length of service..$^{92}$ Length of service has also traditionally been seen as an objective measure, which reduces employer discretion in the redundancy process. ${ }^{93}$ In SEPPP2, age was used to select for compulsory redundancy in $4 \%$ of establishments with recent redundancies or with selection criteria for redundancy in place; and length of service was used by $42 \%$ of those establishments. ${ }^{94}$

The prevalence of youth wages, seniority and experience-based pay, and length of service criteria in redundancy reveal that age and length of service are ubiquitous in modern labour law practices. This, then, flags the broader question of whether it is legitimate for labour law and employers to use experience or length of service as criteria in employment, particularly given it is nearly impossible to

\footnotetext{
${ }^{89}$ ibid 42.

90 ibid 45.

${ }^{91}$ Declan O’Dempsey and Anna Beale, 'Age and Employment' (2011) 93.

${ }^{92}$ Alternatively, it might reflect the idea that older workers are more vulnerable in the event of redundancy or dismissal: this idea is discussed in Part 3C below.

${ }^{93}$ Malcolm Sargeant, 'Age Discrimination, Redundancy Payments and Length of Service' (2009) 72 Modern Law Review 628, 628.

${ }^{94}$ Metcalf and Meadows (n 15) 73.
} 
distinguish differences in length of experience or service from differences in age. At a general level, it is clear that age discrimination legislation is not designed to force employers to employ unqualified workers: according to the Preamble to the Framework Directive: 'This Directive does not require the recruitment, promotion, maintenance in employment or training of an individual who is not competent, capable and available to perform the essential functions of the post concerned' ${ }^{95}$ This is consistent with the occupational requirements exception to the EqA, which provides that employers do not contravene the EqA by imposing occupational requirements that are a proportionate means of achieving a legitimate aim. ${ }^{96}$ It would fundamentally undermine the legitimacy of equality legislation if its effect was to force employers to engage unqualified staff. Thus, skills and experience must obviously play some role in labour law and employer practices, including in the recruitment process. The question, though, is how far this role should extend: should age, experience and/or length of service also determine pay rates, employment conditions and termination practices?

The CJEU has endorsed the use of length of service and experience in determining pay structures where there is evidence that this is a proportionate means of achieving a legitimate aim. ${ }^{97}$ Further, as noted in Hütter, 'Rewarding experience that enables the worker to perform his duties better is, as a general rule, acknowledged to be a legitimate aim' of wage policy. ${ }^{98}$ This approach was endorsed

\footnotetext{
${ }^{95}$ Preamble to the Framework Directive, para 17.

${ }^{96}$ EqA sch 9, s 1(1).

${ }^{97}$ See, for example, Hütter (n 70); C-297/10 Hennigs v Eisenbahn-Bundesamt [2012] 1 CMLR 18; C501/12 Specht v Land Berlin [2014] ICR 966; C-20/13 Unland v Land Berlin [2015] ICR 1225.

${ }^{98}$ Hütter (n 70) para 47.
} 
in C-297/10 Hennigs $v$ Eisenbahn-Bundesamt, ${ }^{99}$ where it was further held that relying on length of service as a criterion to achieve that aim was generally appropriate, 'since length of service goes hand in hand with professional experience'. ${ }^{100}$

However, the use of age-based pay scales is more problematic. The CJEU distinguished the provision in Hütter from a provision seeking to reward experience, as the provision created a difference in how experience was to be recognised, depending on the age at which that experience was acquired. The provision, then, had 'no direct relationship with the aim, so far as the employer is concerned, of rewarding professional experience.' ${ }^{101}$ Similarly, in Hennigs, a pay scale in a collective agreement where initial basic pay varied solely based on chronological age at the date of appointment, not length of service or experience, ${ }^{102}$ went beyond what was appropriate and necessary for recognising professional experience prior to appointment. ${ }^{103}$ However, the CJEU opined that a pay system based on length of service or professional experience - but not age - would be 'better adapted to achieving the legitimate aim', even if, for younger workers, age would generally correspond with professional experience and length of service. ${ }^{104}$ Thus, the CJEU appeared untroubled by the link between age, experience and length of service, so long as chronological age was not explicitly built into the pay structure. Again, in C-

\footnotetext{
${ }^{99}$ Hennigs (n 97) para 72.

100 ibid para 74. See also Specht (n 97) paras 48, 50.

${ }^{101}$ Hütter (n 70) para 47.

${ }^{102}$ Hennigs (n 97) para 75.

103 ibid para 77.

104 ibid.
} 
501/12 Specht $v$ Land Berlin, ${ }^{105}$ the CJEU held that a pay system that allocated initial pay steps using chronological age alone went beyond what was necessary to take into account professional experience acquired prior to appointment. ${ }^{106}$ Thus, while rewarding experience is a legitimate aim of wages policy, and recourse to length of service as a criterion is appropriate for achieving that aim, the use of age as a criterion is not. ${ }^{107}$

The (limited) case law in the UK has reached similar conclusions. In Flynn $v$ Department of Social Development ${ }^{108}$ the Tribunal upheld a pay agreement with incremental pay scales and a length of service criterion. The claimants argued that the agreement was indirectly discriminatory on the grounds of age: older employees would be higher up the spine points in each of the pay scales, meaning they were paid more for doing the same job. ${ }^{109}$ In considering whether the provisions were justified, the Tribunal considered: the respondent's limited resources; collective assent to the pay agreement; the importance of retaining, motivating and rewarding the experience of staff; and the need to remove unnecessary complexities and inconsistencies, and ensure fairness and transparency, in the pay system. Further, the pay agreement was

\footnotetext{
105 Specht (n 97).

106 ibid para 51.

107 ibid paras 47-52. Specht was followed in Unland (n 97), which related to judicial pay scales. 108 [2012] NIIT 00086_08IT (01 February 2012).

${ }^{109}$ See similarly Harrison v Ministry of Defence (2010) ET 2403651/2008 (30 July 2010), [2010] Eq LR 223, a pre-hearing review where the claimants challenged pay systems in place in government departments where pay and benefits (including holiday entitlements) were determined by length of service. The claimants argued that individuals were fully competent in their roles before reaching the maximum entitlement, and therefore were paid less than older workers to fulfill the same role.
} 
only intended to be a transitional arrangement, with further steps to reduce incremental pay periods to be taken in the next agreement. Weighing these factors, the Tribunal held the pay agreement to be a proportionate means of achieving a legitimate aim. Again, this supports the use of length of service to determine pay rates, at least in transitional agreements. In sum, then, young workers may struggle to challenge pay structures based on length of service or years of experience, which will likely be seen as justified in many cases. This will cover the vast majority of pay systems, which are more likely to use length of service or years of experience (rather than age) as a reference point.

There is a consensus in the case law, then, that experience and length of service can legitimately be taken into account in setting pay, even where this closely relates to age. This is consistent with the case law on equal pay. ${ }^{110}$ In C-109/88 Danfoss, ${ }^{111}$ the CJEU held that while length of service as a criterion might disadvantage women, as women may have entered the labour market more recently or had more frequent career interruptions, the employer was 'free to reward it without having to establish the importance it has in the performance of specific tasks entrusted to the employee.' 112 This was because length of service 'goes hand in hand with experience and ... experience generally enables the employee to perform his duties better'. ${ }^{113}$ Therefore, no special justification was required to use length of service as a

\footnotetext{
${ }^{110}$ For further discussion of this case law, see Sargeant, 'Age Discrimination, Redundancy Payments and Length of Service' (n 93) 630-33.

${ }^{111}$ [1989] ECR 3199.

112 ibid para 24.

113 ibid.
} 
criterion in the pay structure. ${ }^{114}$ This was clarified in $\mathrm{C}-17 / 05$ Cadman $v$ Health \& Safety Executive. ${ }^{115}$ Like in Danfoss, the CJEU in Cadman held that rewarding experience that enables a worker to perform their duties better is a legitimate objective of pay policy, and using length of service as a criterion is appropriate to achieve that objective. ${ }^{116}$ However, there could be situations where an employer will need to justify recourse to length of service, particularly where a worker offers 'evidence capable of giving rise to serious doubts as to whether recourse to the criterion of length of service is, in the circumstances, appropriate to attain the abovementioned objective. ${ }^{117}$ The employer must then show that the general rule linking length of service, experience and job performance applies to the job at hand. ${ }^{118}$ Therefore, while length of service is generally a legitimate criterion for determining pay scales, there may be some situations where the assumed link between length of service, experience and job performance is called into question, requiring the employer to justify their use of length of service to determine pay.

The employment situation of younger workers is one of the areas where length of service and experience could well be disaggregated from performance. Length of experience is increasingly being disaggregated from productivity, particularly in the sectors and roles that employ young workers, where there are many jobs that do not require high levels of skill or experience. With the growth in low-skill work in the hospitality, retail and catering sectors, Lucas and Keegan question the distinctiveness

\footnotetext{
114 ibid para 25.

115 [2006] ECR I-9583.

116 ibid para 34-35.

117 ibid para 38.

118 ibid.
} 
of the employment of young workers aged 16 and $17 .{ }^{119} \mathrm{~A}$ disproportionate number of younger workers are employed in unskilled and service roles, where the productivity gains from experience are minimal (see Table 2).

${ }^{119}$ Rosemary Lucas and Shobana Nair Keegan, 'Young Workers and the National Minimum Wage' (2007) 26 Equal Opportunities International 573. 


\begin{tabular}{|c|c|c|c|c|c|c|c|c|c|c|}
\hline & & $\begin{array}{r}\text { Higher } \\
\text { managerial } \\
\text { and } \\
\text { professional }\end{array}$ & $\begin{array}{r}\text { Lower } \\
\text { managerial } \\
\text { and } \\
\text { professional }\end{array}$ & $\begin{array}{l}\text { Intermediate } \\
\text { occupations }\end{array}$ & $\begin{array}{r}\text { Small } \\
\text { employers } \\
\text { and own } \\
\text { account } \\
\text { workers }\end{array}$ & $\begin{array}{r}\text { Lower } \\
\text { supervisory } \\
\text { and technical }\end{array}$ & $\begin{array}{r}\text { Semi-routine } \\
\text { occupations }\end{array}$ & $\begin{array}{r}\text { Routine } \\
\text { occupations }\end{array}$ & $\begin{array}{r}\text { Never } \\
\text { worked, } \\
\text { unemployed, } \\
\text { and not } \\
\text { elsewhere } \\
\text { classified }\end{array}$ & Total \\
\hline \multirow[t]{2}{*}{$16-17$} & Count & 4 & 24 & 61 & 7 & 42 & 131 & 113 & 6395 & 6777 \\
\hline & $\begin{array}{l}\% \text { of those in } \\
\text { work }\end{array}$ & 1.05 & 6.28 & 15.97 & 1.83 & 10.99 & 34.29 & 29.58 & & 100.00 \\
\hline \multirow[t]{2}{*}{ 18-19 } & Count & 29 & 172 & 322 & 46 & 218 & 671 & 431 & 4153 & 6042 \\
\hline & $\begin{array}{l}\% \text { of those in } \\
\text { work }\end{array}$ & 1.54 & 9.11 & 17.05 & 2.44 & 11.54 & 35.52 & 22.82 & & 100.00 \\
\hline \multirow[t]{2}{*}{$20-24$} & Count & 465 & 1710 & 1807 & 403 & 955 & 2446 & 1563 & 4785 & 14134 \\
\hline & $\begin{array}{l}\% \text { of those in } \\
\text { work }\end{array}$ & 4.97 & 18.29 & 19.33 & 4.31 & 10.21 & 26.16 & 16.72 & & 100.00 \\
\hline \multirow[t]{2}{*}{ All ages } & Count & 23975 & 44233 & 23649 & 17542 & 13536 & 24701 & 18555 & 76731 & 242922 \\
\hline & $\begin{array}{l}\% \text { of those in } \\
\text { work }\end{array}$ & 14.43 & 26.62 & 14.23 & 10.56 & 8.14 & 14.86 & 11.16 & & 100.00 \\
\hline
\end{tabular}

Table 2: Age Bands by National Statistics Socio-Economic Classification Major Group (Standard Occupational Classification 2010 based) (Source: 2016 Annual Population Survey, author's own calculations) 
This reflects a broader labour market shift towards non-routine service roles: Holmes and Mayhew's analysis of the Labour Force Survey demonstrates that the number of non-routine service roles increased by 72.2 per cent between 1981 and $2008 .{ }^{120}$ If younger workers are employed in low skill sectors, then there is less of an argument that skill or experience matters in securing organisational productivity and efficiency. ${ }^{121}$ Lower wages for young people may therefore merely perpetuate less favourable treatment on the grounds of age, ${ }^{122}$ and do not reflect differences in productivity.

This, then, questions a key rationale for youth wages, and challenges the use of length of service to determine pay rates in some roles and sectors. Following the approach in Cadman, employers will likely need to justify the reliance on length of service to determine pay, to show the link between service, experience and job performance in low-skill and service roles. This may prove challenging: indeed, in a slightly different setting, it has proven difficult for employers to justify a reliance on length of service in service roles in the hospitality sector. In Bloomfield $v$ Whitbread Group plc, ${ }^{123}$ which related to performance management of a younger worker, the employer failed to show that there was a legitimate aim behind taking length of service into account in a disciplinary process. The Tribunal held that it was 'obvious and unarguable' that considering length of service in the disciplinary process would have an adverse impact on younger workers, particularly those aged 17 and under, as

\footnotetext{
${ }^{120}$ Craig Holmes and Ken Mayhew, The Changing Shape of the UK Job Market and its Implications for the Bottom Half of Earners (Resolution Foundation, 2012) 5.

${ }^{121}$ Sargeant, 'The UK National Minimum Wage and Age Discrimination' (n 86) 353.

${ }^{122}$ Lucas and Keegan (n 119).

${ }^{123}$ [2013] EqLR 191.
} 
they had less opportunity to accrue length of service. ${ }^{124}$ The employer failed to show that there was a legitimate aim underlying this practice: in the absence of evidence, the Tribunal refused to assume that length of service meant an employee posed less of a risk of misconduct, or that length of service equated to more value to the business, particularly given the unskilled nature of hospitality work. Thus, the practice of considering length of service in the disciplinary process was not a proportionate means of achieving a legitimate aim. This case illustrates the very real challenges some employers will face in showing that length of service or experience is related to work performance for younger workers. This could significantly disrupt established pay systems that use length of service as a criterion.

The disaggregation of length of service, experience and work productivity would not just affect pay systems: it also has consequences for redundancy systems and notice periods for dismissal, where age and length of service are often used as criterion to determine eligibility and benefits. ${ }^{125}$ In SEPP2, $40 \%$ of establishments with recent redundancies or with selection criteria in place for redundancy used enhanced redundancy payments: length of service was used to enhance payments in $31 \%$ of establishments; and age was used in $8 \%$ of establishments. ${ }^{126}$ Age and length of service are also used to select for redundancy: in SEPP2, age was used to select for compulsory redundancy in $4 \%$ of establishments with recent redundancies or with selection criteria for redundancy in place; and length of service was used by $42 \%$ of

\footnotetext{
124 ibid [37].

${ }^{125}$ Sargeant, 'Age Discrimination, Redundancy Payments and Length of Service' (n 93) 628. See, for example, EqA sch $9 \mathrm{~s} \mathrm{13,} \mathrm{which} \mathrm{includes} \mathrm{an} \mathrm{exception} \mathrm{for} \mathrm{the} \mathrm{use} \mathrm{of} \mathrm{'enhanced} \mathrm{redundancy} \mathrm{payments'.}$ ${ }^{126}$ Metcalf and Meadows (n 15) 76.
} 
those establishments. ${ }^{127}$ Similarly, age was used to select for voluntary redundancy in $2 \%$ of establishments that had had redundancies in the previous five years or had eligibility criteria for voluntary redundancy. ${ }^{128}$ Finally, statutory notice periods for dismissal are based on length of service. ${ }^{129}$

Length of service has been implicitly endorsed by the CJEU as a legitimate criterion in the context of notice periods for dismissal. In C-555/07 Kücükdeveci v Swedex $G m b H^{130}$ it was held that not taking into account experience under the age of 25 when determining notice periods for dismissal was not proportionate. However, the provision of longer periods of notice based on the employee's length of service was not challenged. Indeed, the CJEU implicitly endorsed 'strengthening the protection of workers according to their length of service in the undertaking' as a legitimate aim. ${ }^{131}$

Using length of service and experience to select for redundancy has also generally been upheld as proportionate in UK case law. For example, the use of length of service as one criterion to select for redundancy in a collective agreement was upheld in Rolls Royce Plc v Unite. ${ }^{132}$ Unusually, it was the employer who challenged the length of service provision in that case. While the use of length of service as one criterion in a redundancy selection process could be indirect

\footnotetext{
127 ibid 73.

128 ibid 78 .

${ }^{129}$ See Employment Rights Act 1996 s 86(1).

${ }^{130}$ [2010] 2 CMLR 33.

131 ibid para 41.

132 [2010] 1 WLR 318.
} 
discrimination on the basis of age, ${ }^{133}$ this was supported by legitimate aims of rewarding long service, loyalty, ${ }^{134}$ and experience; ${ }^{135}$ and 'achieving a stable workforce in the context of a fair process of redundancy selection. ${ }^{136}$ Wall LJ saw rewarding service in a redundancy selection process as 'an entirely reasonable and legitimate employment policy, and one which a conscientious employer would readily and properly negotiate with a responsible Trade Union. ${ }^{\text {137 }}$ The proportionality of the provision was supported by the fact that length of service was only one criterion in the redundancy process, and was not determinative; ${ }^{138}$ that length of service was 'entirely consistent with the overarching concept of fairness', as there was no evidence that younger employees did not accept the provision; ${ }^{139}$ and that the term was collectively negotiated. ${ }^{140}$

Similarly, in both MacCulloch v Imperial Chemical Industries plc ${ }^{141}$ and Lockwood v Department of Work and Pensions, ${ }^{142}$ redundancy schemes where payments were determined by reference to both length of service and age were upheld

\footnotetext{
133 ibid [100] (Wall LJ), [155] (Arden LJ); $c f$ [142]-[143] (Aikens LJ).

134 ibid [95], [100] (Wall LJ).

135 ibid [156] (Arden LJ).

136 ibid [100] (Wall LJ). See also [157] (Arden LJ), which describes 'implement[ing] a scheme for redundancy in a peaceful fashion.'

137 ibid [95] (Wall LJ).

138 ibid [100] (Wall LJ), [162] (Arden LJ).

139 ibid [100] (Wall LJ).

140 ibid [162] (Arden LJ); $c f$ Aikens LJ, who held that a final decision could not be made on this point on the material before the court: [147].

${ }^{141}$ [2008] IRLR 846.

142 [2013] EWCA Civ 1195, [2014] ICR 1257.
} 
as proportionate means of achieving legitimate aims, including the legitimate aim of encouraging and rewarding employee loyalty ${ }^{143}$ and service. ${ }^{144}$ In Boyle v George Best Belfast City Airport, ${ }^{145}$ the use of a criterion of five years' service for redundancy selection was not even seen to place persons of the same age as the claimant (at age 37) at a particular disadvantage when compared with a comparator aged 40 or over. ${ }^{146}$

In contrast, in Hannell v Rydon Group Ltd, ${ }^{147}$ using length of experience to select for redundancy was not proportionate, as achieving full points on this criterion (which was worth 40 out of 95 points) would have required 16 years of industry experience, which younger workers like the claimant were '[s]elf evidently' unable to achieve. ${ }^{148}$ The use of length of experience was supported by the legitimate aim of ensuring workforce stability by retaining workers with the most relevant experience. ${ }^{149}$ However, the criterion would only be proportionate if the employer could show that 'additional years experience resulted or was likely to result in better performance in the role. ${ }^{150}$ The employer assumed that there was a relationship between experience and performance, but did not produce any evidence to that effect. ${ }^{151}$ While the Tribunal acknowledged that it might often be relatively easy to

\footnotetext{
${ }^{143}$ MacCulloch v Imperial Chemical Industries plc (n 141) [14], [45]-[46].

${ }^{144}$ Lockwood v Department of Work and Pensions (n 142) [15].

145 [2012] NIIT 00987_11IT (9 March 2012).

146 ibid [28].

147 [2012] EqLR 903.

148 ibid 903, [44].

149 ibid 904, [46].

150 ibid 904, [46].

151 ibid 904, [46].
} 
justify a criterion based on experience, in this case there was no evidence produced regarding how the other employee had more or better experience than the claimant, or how their different experience was relevant to the role. ${ }^{152}$ The Tribunal therefore held that it was impossible to assess whether the provision was proportionate, and the employer had not discharged their burden to objectively justify the provision. This situation appears similar to that envisaged in Cadman, where the assumed link between length of service, experience and job performance is called into question, requiring the employer to justify their use of length of service or experience to select for redundancy. Hannell and Bloomfield suggest that, in some cases, courts and tribunals will actively scrutinise the use of length of service as a criterion, and its assumed link with productivity. If a rigorous approach is taken to addressing the tension between productivity and equal treatment, as appears the case in Hannell and Bloomfield, an appropriate balance between these competing interests can be found, which allows employers to reward skill and experience, while recognising the productive value of young workers' labour.

\section{Intergenerational fairness}

The third tension evident in age discrimination law is that between intergenerational fairness and equal treatment. For older workers, this generally manifests in the idea that older workers should 'make way' for the young, and relinquish their positions to make room for young people's recruitment, ${ }^{153}$ allocating positions more 'fairly'

\footnotetext{
152 ibid [47].

${ }^{153}$ Georgiev (n 55) para 45; C-45/09 Rosenbladt v Oellerking Gebäudereinigungsges [2011] 1 CMLR 32, paras 43, 60-62; C-159/10 and C-160/10 Fuchs v Land Hessen [2011] 3 CMLR 47, paras 47, 49; Case C-141/11 Hörnfeldt v Posten Meddelande AB [2012] EUECJ C-141/11 (5 July 2012), para 29.
} 
between the generations. ${ }^{154}$ This notion of intergenerational fairness is motivated by the 'fair innings' argument, which dictates that employment policy should take into account all benefits older workers have received over their lifetime: ${ }^{155}$ by old age (or, at least, the retirement age), older workers have benefitted from a substantial period in the labour market, and this benefit offsets any ill-treatment imposed due to fixed retirement ages. It is assumed that this process is 'fair' and 'bloodless', ${ }^{156}$ as all workers experience the same benefits and detriments over the life course. This idea of 'intergenerational fairness' is well recognised in the case law relating to old age discrimination, ${ }^{157}$ though it has been repeatedly critiqued by scholars. ${ }^{158}$

The fair innings argument and intergenerational fairness aims are generally seen as advantaging younger workers, allowing for positions to be opened up to facilitate younger workers' access to employment. The tension, then, is between older workers' rights to not be discriminated against, and younger people's interests in having access to employment opportunities. ${ }^{159}$ However, these arguments can also be

${ }^{154}$ Georgiev (n 55) paras 45-46, 66; C-411/05 Palacios de la Villa v Cortefiel Servicios SA [2007] ECR I-8531, para 53; C-341/08 Petersen v Berufungsausschuss für Zahnärzte für den Bezirk Westfalen-Lippe [2010] 2 CMLR 31, para 65; Rosenbladt (n 153) para 43. For further discussion, see Elaine Dewhurst, 'Intergenerational Balance, Mandatory Retirement and Age Discrimination in Europe: How Can the ECJ Better Support National Courts in Finding a Balance between the Generations?' (2013) 50 Common Market Law Review 1333.

${ }^{155}$ Fredman (n 79) 47.

${ }^{156}$ Richard Posner, Aging and Old Age (University of Chicago Press 1995) 355.

${ }^{157}$ See Seldon (n 84) [56].

${ }^{158}$ See Fredman (n 79) 47; Dewhurst (n 154).

${ }^{159}$ Lucy Vickers and Simonetta Manfredi, 'Age Equality and Retirement: Squaring the Circle’ (2013)

42 Ind Law J 61, 68. 
inverted to the detriment of younger workers, and used to undermine their right to fair and equal treatment. For example, young people's overrepresentation in precarious and low-wage work is often seen as a natural and transitory 'rite of passage': in time, young workers will progress to more secure, better paid positions, reaping the benefits of the labour market later in their life course. ${ }^{160}$ Thus, while young workers' vulnerability in the labour market is seen as problematic, it is not as problematic as it would be if it were a permanent state of affairs. If young workers' situation is transitory, this reduces the need for legal intervention to challenge and address employment practices in the workplace. ${ }^{161}$ Indeed, a period of relative disadvantage in the labour market has been seen as a formative and 'character building' experience. ${ }^{162}$

This variation on the fair innings argument, which sees ill treatment as being offset by all the advantages that one will later experience over working life, ignores the potential scarring effects of poor work: ${ }^{163}$ precarious work can become a trap. While this is particularly the case for those at the bottom end of the labour market

\footnotetext{
${ }^{160}$ See, for example, Stuart Tannock, Youth at Work: The Unionized Fast-Food and Grocery Workplace (Temple University Press 2001) xii.

${ }^{161}$ See C-432/14 Ov Bio Philippe Auguste SARL [2015] EUECJ where the CJEU held that not paying students employed during their vacation an end-of-contract payment was not age discrimination, as the position of students in the workforce was not comparable to that of other workers: para 39.

${ }^{162}$ Herbert W Marsh and Sabina Kleitman, 'Consequences of Employment During High School: Character Building, Subversion of Academic Goals, or a Threshold?' (2005) 42 American Educational Research Journal 331, 332, 334.

${ }^{163}$ David S Pedulla, 'Penalized or Protected? Gender and the Consequences of Nonstandard and Mismatched Employment Histories' (2016) 81 American Sociological Review 262, 280.
} 
(such as in the cleaning and catering industries), ${ }^{164}$ it is also a risk for skilled workers: a period of skill underutilisation can be as scarring as a period of unemployment in later job prospects. ${ }^{165}$ For young workers, precarious work can define their experience of employment, ${ }^{166}$ exacerbate existing class differences ${ }^{167}$ and potentially create 'a "new" route to lasting poverty and long-term marginality.' 168 There is increasing evidence that few younger workers transition from temporary to permanent jobs, challenging the idea that poor jobs can act as a route to better employment. ${ }^{169}$ Instead, young people are increasingly occupying a series of poor jobs. ${ }^{170}$ Thus, young workers consigned to precarious, poor jobs may never obtain decent employment, making the fair innings argument fundamentally inappropriate in this context. ${ }^{171}$

The fair innings argument is also used to justify lower pay and inferior benefits and conditions for younger workers, on the basis that they have less onerous familial and financial needs than older workers. Further, because of these lower needs, young workers can be expected to adapt more easily to the loss of a job, including by

\footnotetext{
${ }^{164}$ Robert MacDonald, 'Precarious Work: Risk, Choice and Poverty Traps' in Andy Furlong (ed), Handbook of Youth and Young Adulthood: New Perspectives and Agendas (Routledge 2009) 170.

${ }^{165}$ Pedulla (n 163) 280.

${ }^{166}$ MacDonald (n 164) 170; Steve Fenton and Esther Dermott, 'Fragmented Careers? Winners and Losers in Young Adult Labour Markets' (2006) 20 Work Employment Society 205.

${ }^{167}$ MacDonald (n 164) 173.

168 ibid 174.

${ }^{169}$ Manos Matsaganis and others, 'Young People and Temporary Employment in Europe' (2013) 28.

170 ibid.

${ }^{171}$ A similar critique may be applied to arguments justifying poor treatment on the basis of 'intergenerational balance': see Dewhurst (n 154).
} 
exhibiting 'flexibility'. ${ }^{172}$ Therefore, where employers have limited funds (which, presumably, is in all cases), older workers may receive preferential treatment, as this supports older workers in their disadvantaged position, and may not be regarded as unfairly onerous on younger workers. This could be seen as a form of intergenerational solidarity, with younger workers sacrificing certain benefits to assist older workers. Again, younger workers are presumed to benefit from more generous benefits and conditions later in their work careers, once they have less 'flexibility' and more substantive financial and familial responsibilities.

The argument that younger workers have lower financial needs than older workers has been rejected in CJEU case law. In Hennigs ${ }^{173}$ the CJEU rejected the argument that a pay scale based on chronological age at the date of appointment was appropriate and necessary to compensate older employees for their greater financial needs. ${ }^{174}$ It was not shown that there was 'a direct correlation between the age of employees and their financial needs. Thus a young employee may have substantial family burdens to bear while an older employee may be unmarried without dependant children.' ${ }^{175}$ However, assuming evidence was available to show this 'direct correlation', the decision may well have been different.

Evidence was offered of the different financial needs of different age groups in Lockwood. ${ }^{176}$ In that case, the provision of lower redundancy pay to younger

\footnotetext{
${ }^{172}$ See the discussion below of Lockwood (n 142).

${ }^{173}$ Hennigs (n 97).

174 ibid para 69.

175 ibid para 70.

${ }^{176}$ Lockwood (n 142).
} 
workers was justified, in part, on the basis that younger employees had fewer family and financial obligations (and therefore should be expected to be more 'flexible'), and 'can generally be expected to react more easily and more rapidly to the loss of their jobs', as they typically suffered unemployment for a shorter period than older workers. ${ }^{177}$ This was supported by evidence of the average age of marriage and first home ownership. While Ms Lockwood's own financial situation was 'more akin to those in the age group above $35^{\prime},{ }^{178}$ it was not practicable to assess individual circumstances in this context. The decision in this case presents a partial and misleading view of young workers' financial commitments: costly rent and family responsibilities are not confined to older workers, or those who are married. Indeed, those with mortgages are the fortunate ones in the modern housing market. ${ }^{179}$ Thus, the approach in Hennigs, which called for robust evidence of the link between age and financial responsibilities, is to be preferred.

Like in Lockwood, CJEU and UK case law generally assumes that younger workers are more 'flexible', resilient and mobile than older workers. As a result, they suffer less from dismissal or redundancy, and require less support to transition to a new job than older workers. In Kücükdeveci ${ }^{180}$ it was argued that younger workers 'generally react more easily and more rapidly to the loss of their jobs and greater

\footnotetext{
177 ibid [50] (Rimer LJ).

178 ibid.

${ }^{179}$ Shelter Media England, 'Shelter Launches Call for Changes to Private Renting' (Shelter, 21 September)

$<\mathrm{http}: / /$ media.shelter.org.uk/home/press_releases/shelter_launches_call_for_changes_to_private_rentin g> accessed 18 February 2015.

${ }^{180}$ Kücükdeveci (n 130).
} 
flexibility can be demanded of them, ${ }^{181}$ and it is 'reasonable to expect a greater degree of personal or occupational mobility' from younger workers, ${ }^{182}$ meaning they require less notice of termination. The CJEU did not inquire into the legitimacy of this aim: even if it was legitimate, the specific provision in that case was not appropriate to achieve the aim, as the notice provisions applied to all employees who were appointed prior to the age of 25 , irrespective of their age at dismissal. ${ }^{183}$

In Rolls Royce, ${ }^{184}$ the use of a length of service criterion in selecting for redundancy was seen as being for the benefit and support of older workers, as 'it was employees who had served longest who were likely to find it most difficult to find new employment.' ${ }^{185}$ Over the long term, this would be fair across generations, as 'All employees, including those who now are disadvantaged by the length of service criterion, stand to benefit at some time from this criterion.' ${ }^{186}$ Therefore, while this provision was for the benefit of older workers now, it would also assist younger workers later in their careers, explicitly incorporating ideas of intergenerational fairness. Of course, given it was the employer in Rolls Royce who was challenging the length of service provision, it appears unlikely that the provision would endure for long enough to be of benefit to younger workers. This provides a concrete example of how, in practice, it is unlikely that younger and older workers will be subject to the same provisions over the course of their working lives, as laws and employment

\footnotetext{
181 ibid para 35.

182 ibid para 39.

183 ibid para 40.

${ }^{184}$ Rolls Royce (n 132).

185 ibid [162] (Arden LJ).

186 ibid.
} 
policies continually change and evolve. ${ }^{187}$ Thus, intergenerational 'fairness' is unlikely to be fair in practice if comparing across generations, ${ }^{188}$ particularly given changing social and economic realities and the decline of employment continuity. ${ }^{189}$

MacCulloch ${ }^{190}$ also related to a redundancy scheme where payments were determined by reference to both length of service and age. The Tribunal held that the scheme was supported by legitimate aims of giving financial protection to older workers, who were more vulnerable in the job market; ${ }^{191}$ and encouraging older workers to leave, creating vacancies for younger workers and avoiding compulsory redundancies. ${ }^{192} \mathrm{~A}$ challenge to this intergenerational fairness aim was resoundingly rejected by the EAT:

It is said that it could not possibly be legitimate to encourage older employees to leave since that is itself age tainted discrimination. However, we do not think the Tribunal is saying that the aim was simply to encourage the older employees to leave: it is indicating that older workers can be a block on recruitment and it encourages turnover and the prevention of blockage in the employment system if some older workers are tempted to leave. That is, in principle, capable of being a legitimate objective. ${ }^{193}$

\footnotetext{
${ }^{187}$ Fredman (n 79) 38.

188 ibid.

${ }^{189}$ Fudge and Zbyszewska (n 36) 146.

${ }^{190}$ MacCulloch (n 141).

191 ibid [15].

192 ibid [16], [47].

193 ibid [47].
} 
Further, it was not necessary to lead evidence that older workers found it more difficult to find work than younger workers: the Tribunal 'was fully entitled to draw from its own experience' that this was the case. ${ }^{194}$ When the case was referred back to the original ET to reconsider the issue of proportionality, the ET held that the scheme was a proportionate means of achieving a legitimate aim, considering particularly that the scheme was acceptable to the workforce as a whole; and rejecting statistics submitted by the claimant to contest that older workers found it more difficult to find work than younger ones.

The decision in MacCulloch, then, sees one redundancy scheme as both supporting older workers, who need additional payments to compensate for their disadvantageous position in the labour market; and supporting younger workers, who will benefit from the opening up of job opportunities. This is a practical means of achieving intergenerational fairness and solidarity. On a more pessimistic view, though, the scheme could also be seen as disadvantaging younger workers, who will receive a lower level of redundancy pay; and putting moral pressure on older workers to relinquish their employment. Thus, the scheme simultaneously infringes the equal treatment principle for both older and younger workers.

At a more fundamental level, this case law assumes that young workers are more likely to move back into employment from unemployment than their older colleagues. ${ }^{195}$ This 'wisdom' has been convincingly questioned by some empirical

\footnotetext{
194 ibid [48].

${ }^{195}$ See Lockwood (n 142).
} 
studies, ${ }^{196}$ particularly at times of high youth unemployment. ${ }^{197}$ Indeed, young people are far from immune from long-term unemployment. Further, young workers form a diverse and heterogeneous cohort, some of whom will particularly struggle to re-enter employment. ${ }^{198}$ Casting all 'young workers' as being resilient in the case of job loss is overly optimistic. Finally, even if young people more easily move back into employment than older workers, this could reflect the lack of employment protection for younger workers. ${ }^{199}$ This circular rationale therefore risks further eroding employment protections and the equal treatment principle.

In sum, then, the use of intergenerational fairness and fair innings arguments to erode the equal treatment principle risks disadvantaging both older and younger workers. Rather than different generations being in conflict or competition, ${ }^{200}$ different (non-prime) generations are being equally disadvantaged by the way courts are resolving this tension. Thus, it is in no generations' interests to pursue intergenerational fairness arguments: a benefit in one area will likely lead to disadvantage in another. Further, policies and practices justified on the basis of

${ }^{196}$ Mike Donnelly and Dora Scholarios, 'Workers' Experiences of Redundancy: Evidence from Scottish Defence-dependent Companies' (1998) 27 Personnel Review 325, 335.

${ }^{197}$ See similarly Fudge and Zbyszewska (n 36) 146.

${ }^{198}$ See, for example, Lisa M Lynch, 'The Youth Labor Market in the Eighties: Determinants of ReEmployment Probabilities for Young Men and Women' (1989) 71 The Review of Economics and Statistics 37 .

${ }^{199}$ See, for example, Lawrence M Kahn, 'The Impact of Employment Protection Mandates on Demographic Temporary Employment Patterns: International Microeconomic Evidence' (2007) 117 The Economic Journal F333.

${ }^{200}$ Vickers and Manfredi (n 159) 67-69. 
intergenerational fairness may disproportionately affect already disadvantaged groups of workers, such as those with disrupted career paths. ${ }^{201}$ There are therefore serious grounds for questioning both intergenerational fairness and fair innings arguments.

Of course, unequal treatment of workers of different ages might be required to achieve equality. ${ }^{202} \mathrm{~A}$ focus on substantive equality, rather than formal equality, could explain how the tension between intergenerational fairness and equal treatment has been resolved in some cases. ${ }^{203}$ These sorts of provisions, which provide additional support to older workers facing redundancy or dismissal, may help to correct maldistribution or disadvantage in the labour market, ${ }^{204}$ and recognise and accommodate workers' individual needs at different ages. ${ }^{205}$ However, this assumes that we have a clear and well-informed idea of the disadvantage facing older and younger workers, ${ }^{206}$ and an effective means of substantively addressing that disadvantage. As the discussion above has shown, the courts often lack an understanding of younger workers' vulnerability in the labour market, disregarding their financial and familial commitments (as in Lockwood) and failing to require evidence that younger workers are more resilient and 'flexible' than their older colleagues (as in MacCulloch). Thus, while the equal treatment principle is unlikely to be sufficient to achieve substantive equality, more rigorous evidence is required before assuming that measures that infringe the equal treatment principle are

\footnotetext{
${ }^{201}$ Fudge and Zbyszewska (n 36) 162.

${ }^{202}$ Fredman (n 30) 2; Fredman (n 79) 38-39.

${ }^{203}$ For further discussion of different conceptions of 'equality', see Fredman (n 30) 8-33.

${ }^{204}$ ibid 2, 26, 197, 199.

205 ibid 30-31.

206 ibid 26.
} 
appropriate to achieve substantive equality in practice. Without this, there is a risk that stereotypical assumptions will be allowed to override the principle of equal treatment. $^{207}$

\section{Discussion and conclusions}

Age discrimination law is beset by tensions. This reflects a fundamental conflict between instrumental or economic aims, which seek to promote integration of workers of all ages in the labour market and an age diverse workforce; and intrinsic or dignity aims, which seek to promote the equal treatment principle. As both direct and indirect age discrimination can be objectively justified under EU and UK law, there is an expectation that these tensions will be negotiated via the proportionality principle. ${ }^{208}$ However, as the preceding sections have illustrated, these tensions are typically resolved in favour of economic or instrumental ends, such as integration, productivity and intergenerational fairness: the equal treatment principle generally comes off second best.

\footnotetext{
207 See Fredman (n 79) 52.

${ }^{208}$ For discussion, see Dagmar Schiek, 'Proportionality in Age Discrimination Cases: Towards a Model Suitable for Socially Embedded Rights' in Ann Numhauser-Henning and Mia Rönnmar (eds), Age Discrimination and Labour Law: Comparative and Conceptual Perspectives in the EU and beyond (Studies in employment and social policy 47, Kluwer Law International 2015). Tensions might also be negotiated via collective bargaining: see Mia Rönnmar, 'Age Discrimination and Labour Law: A Comparative Analysis' in Ann Numhauser-Henning and Mia Rönnmar (eds), Age Discrimination and Labour Law: Comparative and Conceptual Perspectives in the EU and beyond (Studies in employment and social policy 47, Kluwer Law International 2015) 430-31.
} 
As this article has explored, this is an issue for both old and young age discrimination. There are striking parallels between how these tensions are resolved in cases of older age discrimination, and how they are resolved in cases involving younger workers. Thus, this does not just reflect a lesser value placed on young age equality: instead, it reflects a devaluing of non-prime age workers generally, and of the principle of age equality. It is therefore inappropriate to depict age discrimination law as representing a conflict between the generations: ${ }^{209}$ rather, both older and younger workers are united by their inferior position in equality law.

While it is inevitable that age discrimination law will generate tensions of this nature, it is not inevitable that courts should so consistently prioritise instrumental ends over equal treatment. Indeed, some cases show a resistance to prioritising instrumental ends. Thus, this article echoes the findings of other scholars, who have criticised the Framework Directive and EqA for placing a lesser value on age equality than protection for other protected characteristics. ${ }^{210}$ Given the repeated deprioritising of the equal treatment principle, it is timely to reconsider whether direct age discrimination should be able to be objectively justified. It is this exception, more than any other, which sets age discrimination law apart from discrimination on other grounds. ${ }^{211}$ Further, it risks significantly limiting the protection available to non-

\footnotetext{
${ }^{209}$ cf Fredman (n 30) 101.

${ }^{210}$ Malcolm Sargeant, 'Mandatory Retirement Age and Age Discrimination' (2004) 26 Employee Relations 151, 154. See further Colm O'Cinneide, 'Constitutional and Fundamental Rights Aspects of Age Discrimination' in Ann Numhauser-Henning and Mia Rönnmar (eds), Age Discrimination and Labour Law: Comparative and Conceptual Perspectives in the EU and beyond (Studies in employment and social policy 47, Kluwer Law International 2015) 54-55.

${ }^{211}$ Fredman (n 30) 106.
} 
prime age workers, and arguably legitimates discrimination on the grounds of age. ${ }^{212}$ One option, then, is to conduct a comprehensive review of this exception. Alternatively, it may be sufficient to consider a different, more rigorous approach to the proportionality test. As O'Cinneide argues, proportionality analysis can be undertaken via either a "light touch "rationality" approach', or a "rigorous proportionality"' test: ${ }^{213}$ many national courts appear to adopt the former approach in relation to age discrimination, ${ }^{214}$ and the CJEU's approach varies according to the nature of the case before it. ${ }^{215}$ The cases discussed above relating to young age discrimination swing between these two approaches. A more rigorous and consistent application of the proportionality test might be sufficient to ensure age discrimination law offers adequate protection for both younger and older workers.

Finally, this article has illustrated the continued pervasiveness of less favourable treatment on the basis of age across the employment life cycle in labour law and employment practices. While it might be difficult to disaggregate broader structural and economic changes from age discrimination, it is clear that less favourable treatment on the basis of age does not assist younger workers in establishing their position in the labour market. This article has demonstrated the very

\footnotetext{
${ }^{212}$ Sargeant, 'The Employment Equality (Age) Regulations 2006' (n 46) 219; Malcolm Sargeant, 'Age Discrimination' in Malcolm Sargeant (ed), The Law on Age Discrimination in the EU (Kluwer Law International 2008) 3; Malcolm Sargeant, 'The European Court of Justice and Age Discrimination' [2011] Journal of Business Law 144, 148.

${ }^{213}$ O'Cinneide, 'Constitutional and Fundamental Rights Aspects of Age Discrimination' (n 210) 53.

214 ibid 69.

${ }^{215}$ Schiek (n 208) 81-82; Claire Kilpatrick, 'The Court of Justice and Labour Law in 2010: A New EU Discrimination Law Architecture' (2011) 40 Ind Law J 280, 291-99.
} 
real significance of less favourable treatment to younger workers' experiences of employment, and the potential inadequacy of existing provisions for protecting young workers' rights. Beyond this, though, it also offers a basis for criticising the limited protection offered to older workers via age discrimination law. Thus, it is a call for a fundamental rethink of the Framework Directive and EqA, and how they are implemented by the courts. A more rigorous focus on individual rights and the equal treatment principle in navigating the tensions of age discrimination law would offer a more coherent and forceful approach to age equality law. ${ }^{216}$

${ }^{216}$ Colm O'Cinneide, 'Comparative European Perspectives on Age Discrimination Legislation' in Sandra Fredman and Sarah Spencer (eds), Age as an Equality Issue: Legal and Policy Perspectives (Hart 2003) 217. 